\title{
ARTICLES
}

\section{MNCs under International Climate Change Regime: Recognizing Atmospheric Absorptive Capacity as the Common Heritage of Mankind}

\author{
Tsung-Sheng Liao*
}

Global warming is a result of human influence. However, little has been done to stabilize greenhouse gas concentrations in the atmosphere to a 'safe' level. An important factor for such dismal state of affairs is that the international community has emphasized far too much on the State-centric approach to combating climate change. The international legal regime does not directly control major emitters or MNCs. This article recognizes the atmosphere as a part of the global commons and the atmospheric absorptive capacity as the common heritage of mankind. Therefore, the international community can pave the way to link global climate change regime and MNCs. Those common interests of the international community can be protected when MNCs turn their production processes green, by redirecting their investment into green technology, and try to alter the negative status quo.

\section{Keywords}

MNCs, Climate Change Regime, Atmospheric Absorptive Capacity, Common Heritage of Mankind

* Associate Professor of International Law at National Chung Cheng University, Taiwan. LL.M./S.J.D. (U. WisconsinMadison). ORCID: http://orcid.org/0000-0002-8009-5227. The author may be contacted at: lawts1@ccu.edu.tw/ Address: Department of Law, National Chung Cheng University, \#168, University Rd., Min-Hsiung Township, Chiayi County, Taiwan 62102. The author wishes to show his gratefulness to reviewers for their insightful comments, and to acknowledge the support from the Ministry of Science and Technology of Taiwan (MOST 102-2410-H-194-067-MY3). DOI: http://dx.doi.org/10.14330/jeail.2016.9.2.04 
Although we often look at corporations as a big part of the problem -

they are after all responsible for most pollution, deforestation, and natural resource degradation - we must look to them as a big part of the solution if we are to deal with global warming and other major issues. ${ }^{1}$

\section{Introduction}

The scientific debate of climate change is conclusory. The Inter-Governmental Panel on Climate Change ("IPCC") states that global warming is unequivocal and it is 'extremely likely' that human influence has been the main cause of this situation. ${ }^{2}$ Policymakers, however, have staggered since the United Nations Framework Convention on Climate Change ("UNFCCC") $)^{3}$ was adopted in Rio de Janeiro in 1992. Atmospheric concentrations of carbon dioxide are increasing at an accelerating rate. The concentration was 356 ppm in 1992 and has increased to 387 ppm in $2009^{4}$ and to 398 ppm in $2014 .^{5}$

Yet, as the international community has placed much emphasis on the Statecentric approach to combat climate change, the international legal regime does not directly apply greenhouse gas emissions reduction regulations to real and major emitters: the multinational corporations ("MNCs"). ${ }^{6}$ Not only the UNFCCC but also its Kyoto Protocol ${ }^{7}$ divides countries into two major groups, i.e., Annex I Parties and non-Annex I Parties. Both categories bear different emissions reduction obligations on the basis of "common but differentiated responsibility with respective capabilities" (hereinafter CBDR principle). ${ }^{8}$ Nevertheless, the CBDR principle requires that only Annex I Parties cut greenhouse gas emissions, without

1 P. Lehner, Changing Markets to Address Climate Change, 35 B.C. EnvtL. Aff. L. Rev. 385 (2008).

2 IPCC, Climate Change 2013: The Physical Science Basis: Summary for Policy Maker (Working Group I, The Fifth Assessment Report) 17 (2013), available at https://www.ipcc.ch/pdf/assessment-report/ar5/wg1/WGIAR5_SPM_ brochure_en.pdf (last visited on Oct. 5, 2016).

3 United Nations Framework Convention on Climate Change of 1992, 1771 U.N.T.S. 107 [hereinafter UNFCCC], available at $\mathrm{https} / / / \mathrm{unfccc}$.int/resource/docs/convkp/conveng.pdf (last visited on Oct. 5, 2016).

4 In 2009, the Copenhagen Accord was reached in COP 15, but without binding effects.

5 See Annual CO2 Data, CO2 Now.Org, available at http://co2now.org/Current-CO2/CO2-Now/annual-co2.html (last visited on Oct. 4, 2015).

6 S. Adelman, Rethinking Human Rights: The Impact of Climate Change on the Dominant Discourse, in HumAN RigHTS and Climate Change 161 (S. Humphreys ed., 2010).

7 Kyoto Protocol to the UN Framework Convention on Climate Change of 1997, 2303 U.N.T.S. 148 [hereinafter Kyoto Protocol], available at http://unfccc.int/kyoto_protocol/items/2830.php (last visited on Oct. 5, 2016).

8 UNFCCC art. 3.1. 
proportionate burden over non-Annex I Parties.

In order to redress that problem, the Paris Agreement to the UNFCCC (hereinafter Paris Agreement) adopted at COP 21 in December 2015 requests all Parties to take measures to deal with global warming on the basis of their "intended nationally determined contributions" ("INDCs"). INDCs are submitted by Parties in the context of their own circumstances, capabilities and priorities. In a different aspect, however, those commitments are voluntary declarations based on 'intended' different emission reductions. INDCs could turn out to be a failure because of each Party's political calculation or the lack of a strong and effective compliance mechanism.

In this battle on climate change, MNCs should not be overlooked because they would often influence on global affairs with significant power as major greenhouse gas emitters. Of the world's 100 largest economic entities in 2000, 51 were corporations, while 49 were countries. ${ }^{9}$ In 2012, the percentage of corporations of the world's 100 largest economic entities slightly decreased, but 40 were still corporations. ${ }^{10}$ The annual revenue of one big MNC is much higher than the combined annual income of each medium size country. Furthermore, these MNCs are hurdles to climate change activism. They have emitted nearly two-thirds of the greenhouse gases since the industrial revolution. ${ }^{11}$ It is worse that MNCs can evade responsibility and produce emissions in the course of business in different jurisdictions.

If MNCs are crucial emitters and are responsible for climate change, bringing MNCs under the global climate change governance regime will be the key to redressing global warming. In this article, the author argues that recognizing the 'atmosphere' as the global commons and the "atmospheric absorptive capacity" as the common heritage of mankind ("CHM") can pave the way to link international climate change legal regime with MNCs. This will lead MNCs to green processes, redirect their investment into green technology, and address the status quo.

The primary purpose of this research is to incorporate MNCs into the international climate change regime. This article is composed of five parts including Introduction and Conclusion. Part two will discuss the definition of MNCs in terms of addressing the climate change question and the failure of legal regimes to regulate MNCs and their emissions. Part three will elucidate the concept and types of CHM and lay out the "atmospheric absorptive capacity" as CHM. Part IV will suggest

9 S. Anderson \& J. Cavanagh, Top 200: The Rise of Corporate Global Power 1-7 (Institute for Policy Studies, 2000), available at http://www.rrojasdatabank.info/top200.pdf (last visited on Oct. 5, 2016).

10 C. Stoklund Corporate Clout 2013: Time for Responsible Capitalism, Global Trends, available at http://www. globaltrends.com/2013/06/04/corporate-clout-2013-time-for-responsible-capitalism-2 (last visited on Oct. 5, 2016).

11 Id. 
that the framework of the International Sea-Bed Authority ("ISA") is a good model to govern $\mathrm{CHM}$ for the atmospheric governance structure. Part V will propose to establish the International Atmosphere Authority ("IAA") to link the international legal regime to MNCs through contracts between them. Thus, the atmospheric common interests of the international community as a whole, including States and non-State actors, will be protected and shared.

\section{Multinational Corporations and Climate Change}

\section{A. Definition of Multinational Corporations and Their Greenhouse Gas Emissions}

MNCs do not have a common definition due to their freedom from effective international control. E.g., the 1977 Tripartite Declaration of Principles concerning Multinational Enterprises and Social Policy of International Labour Organization provides: "Multinational enterprises include enterprises, whether they are of public, mixed or private ownership, which own or control production, distribution, services or other facilities outside the country in which they are based."12 The 2003 Draft Norms on the Responsibilities of Transnational Corporations and Other Business Enterprises with regard to Human Rights, prepared by the United Nations SubCommission on the Promotion and Protection of Human Rights, stipulates: "The term 'transnational corporation' refers to an economic entity operating in more than one country or a cluster of economic entities operating in two or more countries - whatever their legal form, whether in their home country or country of activity, and whether taken individually or collectively." "13 For the purposes of this article, however, a MNC may be defined as a group of economic entities established in more than one country and cooperating with each other in various ways to conduct economic activities. ${ }^{14}$

12 International Labor Office, The Tripartite Declaration of Principles concerning Multinational Enterprises and Social Policy, princ. 6 (4th ed. 2006) [hereinafter Tripartite Declaration], available at http://www.ilo.org/wcmsp5/ groups/public/---ed_emp/---emp_ent/---multi/documents/publication/wcms_094386.pdf (last visited on Oct. 5, 2016).

13 Draft Norms on the Responsibilities of Transnational Corporations and Other Business Enterprises with regard to Human Right, United Nations Sub-Commission on the Promotion and Protection of Human Rights. See U.N. Doc. E/ CN.4/Sub.2/2003/12 (Aug. 26, 2003), available at https://documents-dds-ny.un.org/doc/UNDOC/GEN/G03/160/08/ PDF/G0316008.pdf?OpenElement (last visited on Oct. 5, 2016).

14 See Multinational Corporations (MNCs), BusinessDictionary, available at http://www.businessdictionary.com/ definition/multinational-corporation-MNC.html (last visited on Oct. 23, 2016). 
MNCs have proven to be crucial actors contributing to greenhouse gas emissions. An Oxfam ${ }^{15}$ report indicates that there are ten big food companies that produce and control most of the food and drinks in grocery stores. ${ }^{16}$ These 'big 10,' having revenues that are more than a billion dollars per day, ${ }^{17}$ "emit so much greenhouse gas through their supply chains that, if they were a single country, they would be the 25th most polluting in the world." 18

According to the report of the Carbon Disclosure Project, the Global 500 emitted 3.6 million metric tons of carbon dioxide equivalent in 2013, either directly (Scope 1$)^{19}$ or indirectly (Scope 2). ${ }^{20}$ This amounts to 10 percent of the world's total greenhouse gas emissions. ${ }^{21}$ Among the Global 500, the 50 largest emitters are accountable for 73 percent of total emissions. ${ }^{22}$ Also, 32 energy sector companies of the Global 500 emit over 31 percent of greenhouse gases globally taking Scope 1, Scope 2 and the "use of product" category, Scope $3^{23}$ together. ${ }^{24}$

Furthermore, from Heede's analysis based on historic fossil fuel and cement production records from 1854 to 2010, some 914 billion metric tons of carbon dioxide equivalent have been traced to 90 international corporations. ${ }^{25}$ These

15 Oxfam is an international confederation of 17 organizations aiming to end global and local injustice and poverty. See Who we are, Oxfam, available at https://www.oxfam.org/en/about/ (last visited on Oct. 4, 2016).

16 They are as follows: Nestle, Coca-Cola, General Mills, Kellogg, Mars, Unilever, PepsiCo, Danone, Mondelez, and Associated British Foods. See Anna Kramer, These 10 Companies Make a Lot of the Food We Buy. Here's How We Made Them Better, Oxfam America, available at http:/www.oxfamamerica.org/explore/stories/these-10-companiesmake-a-lot-of-the-food-we-buy-heres-how-we-made-them-better (last visited on Oct. 5, 2016).

17 Id.

18 Id.

19 Scope 1 means all direct greenhouse gas emissions from one entity. Direct greenhouse gas emissions are those from sources that are owned or controlled by the entity. See World Resources Institute \& WorLd Business Council FOR Sustainable Development, The Greenhouse Gas Protocol: A Corporate Accounting and Reporting Standard 25 (2004), available at http://C:/Users/USER/Downloads/ghg-protocol-revised.pdf (last visited on Oct. 5, 2016).

20 Scope 2 means indirect greenhouse gas emissions from consumption of purchased electricity, heat or steam. Id. See also Carbon Disclosure Project, Global 500 Climate Change Report 8 (2013), available at https://www.pwc.es/es/ publicaciones/gestion-empresarial/assets/global-500-climate-change-report-2013.pdf (last visited on Oct. 5, 2016).

21 In 2013, global carbon dioxide equivalent emissions reached 35.3 billion metric tons. See J. Olivier Et AL., TrendS IN Global CO 2 Emissions: 2014 Report 10 (2014), available at http://www.pbl.nl/sites/default/files/cms/publicaties/ PBL_2014_Trends_in_global_CO2_emisions_2014_1490_0.pdf (last visited on Oct. 5, 2016).

22 Supra note 20.

23 Scope 3 means "[o]ther indirect emissions, such as the extraction and production of purchased materials and fuels, transport-related activities in vehicles not owned or controlled by the reporting entity, electricity-related activities not covered in Scope 2, outsourced activities, waste disposal, etc." See supra note 19.

24 J. Moorhead \& T. Nixon, Global 500 Greenhouse Gas Report: The Fossil Fuel Energy Sector 2-3 (2015), available at http://thomsonreuters.com/content/dam/openweb/documents/pdf/corporate/Reports/global-500-greenhouse-gasreport-fossil-fuel-energy-sector.pdf (last visited on Oct. 5, 2016).

25 R. Heede, Tracing Anthropogenic Carbon Dioxide and Methane Emissions to Fossil Fuel and Cement Producers, 1584-2010, 122 Climate Change 234 (2013), available at http://www.climateaccountability.org/pdf/Heede\%20 
90 'carbon major' corporations, ${ }^{26}$ including 50 investor-owned, 31 State-owned, and 9 nation-State producers of fossil fuel and cement, emitted 63 percent of the world's cumulative carbon dioxide and methane emissions between 1751 to $2010 .^{27}$ Therefore, these gigantic MNCs need to do more to reduce emissions and take proactive measures to combat climate change based on "the polluter and user pays" principles.

\section{B. Regulations Governing Multinational Corporations}

As main actors engaged in today's global economy, MNCs control most trade and investment activities. However, they have traditionally been in the regulatory gray zone between domestic and international law. Without appropriate regulations, MNCs can evade legal responsibility through the manipulation of their characteristics after creating local or global externalities.

Theoretically, a State has effective jurisdiction over an MNC through its domestic laws, especially through corporation-related regulations. All actions of MNCs within a State's jurisdiction should comply with the host State's regulations and its enforcement system. When MNCs violate domestic laws, they should be responsible for what they have done. Nonetheless, domestic laws treat sub-holding corporations and subsidiaries as independent legal entities with their rights and obligations distinct from the parent corporation. ${ }^{28}$ Although subsidiaries usually conduct assigned segments of one single business arranged by the parent corporation, the traditional view of domestic laws shields parent corporations from vicarious liability. ${ }^{29}$

Meanwhile, MNCs and individuals are non-State actors, which are not subjects of international law. ${ }^{30}$ Ian Brownlie considers the law governing MNCs to be still

TracingAnthropogenic\%20ClimCh\%20Nov13.pdf (last visited on Oct. 5, 2016).

26 Top 20 carbon major corporations are as follows: Chevron, Exxon Mobil, Saudi Aramco, BP, Gazprom, Royal Dutch/ Shell, National Iran Oil Company, Pemex, Conoco Phillips, Petroleos de Venezuela, Coal India, Peabody Energy, Total, Petro China, Kuwait Petroleum, Abu Dhabi NOC, Sonatrach, Consol Energy Inc., BHP-Billiton, and Anglo American.

27 Supra note 25.

28 P. Blumberg, Accountability of Multinational Corporations: The Barriers Presented by Concepts of the Corporate Juridical Entity, 24 Hastings InT'L \& Comp. L. Rev. 304 (2001), available at http://digitalcommons.uconn.edu/cgi/ viewcontent.cgi?article=1136\&context=law_papers (last visited on Oct. 5, 2016).

29 J. Paul, Holding Multinational Corporations Responsible under International Law, 24 Hastings InT'L \& Comp. L. REv. 292 (2001), available at http://repository.uchastings.edu/cgi/viewcontent.cgi?article=1622\&context=faculty scholarship (last visited on Oct. 5, 2016).

30 Positivists tend to view States as the only subjects of international law. See H. Kelsen, Principles of International LAw 438-9 (1966); D. Eshanov, The Role of Multinational Corporations from the Neoinstitutionalist and International 
within the jurisdiction of domestic law, because MNCs are entities established in accordance with domestic law. ${ }^{31}$ In the Anglo-Iranian Oil Company case in 1951, the International Court of Justice ("ICJ") decided that: “... the contract signed between the Iranian Government and the Anglo-Persian Oil Company ... is nothing more than a concessionary contract between a government and a foreign corporation." 32 The Court did not accept that a corporation was a subject of international law. It is still a mainstream idea of contemporary international law. Only treaties can be applied in the ICJ, and contracts between governments and corporations are not equivalent to treaties. ${ }^{33}$ Hence, the ICJ has no jurisdiction over MNCs or their contractual disputes. Further, the International Law Commission's Draft Articles on the Responsibility of States for Internationally Wrongful Acts tried assigning vicarious responsibility of MNCs to their States, but it was not successful. ${ }^{34}$ Because MNCs are not a subject of international law, the international community attempted to exercise control directly through the UN resolutions and indirectly through international law as absorbed into domestic law in recent years.

MNCs are two-faced. They not only destroy the environment, but also promote sustainable development. As direct obligations should be imposed on MNCs, they are able to provide new technologies, financial and human resources to improve the environment. Hence, it is necessary to bring MNCs under the international legal regime on climate change.

\section{Atmospheric Absorptive Capacity as CHM}

When combating climate change, MNCs can be the solution as well as the problem. While recognizing the 'atmosphere' as the 'global commons,' the "atmospheric absorptive capacity" can be deduced as CHM. Further, international climate change regime can "extend an olive branch" to MNCs.

Law Perspectives: The Concept of the Three-Level Game, 16 N.Y.U. ENvTL. L. J. 116-8 (2008), available at http:/ papers.ssrn.com/sol3/papers.cfm?abstract_id=1435028 (last visited on Oct. 5, 2016).

31 I. Brownlie, Principles of Public International Law 66 (7th ed. 2008).

32 Anglo-Iranian Oil Co. (U.K. v. Iran), Preliminary Objection, 1952 I.C.J. 112 (June 22), available at http://www.icj-cij. org/docket/files/16/1997.pdf (last visited on Oct. 24, 2016).

33 Id.

34 Draft Articles on Responsibility of States for Internationally Wrongful Acts, art. 5, 53 U.N. GAOR Supp. (No. 10) at 43, U.N. Doc. A/56/83 (2001), available at http://www.un.org/ga/search/view_doc.asp?symbol=A/res/56/83 (last visited on Oct. 26, 2016). 


\section{A. Global Commons' Resources as CHM}

Terms of the global commons and CHM appeared decades ago as an indication of areas and natural resources beyond the control of any national sovereignty. The difference and application between these two important definitions, however, are not always united or clearly distinguished. The areas or regions out of any State's jurisdiction are referred to as the 'global commons,' such as the high seas and outer space. ${ }^{35}$ In other words, the global commons may be described as the 'space' where no distinct State sovereignty is applied. All human beings can conduct some activities freely on or within this global space. ${ }^{36}$ Instead of claiming ownership, States could access the global commons for exploration and exploitation.

The CHM institution was created to deal with resources in the global commons, such as the sea-bed and the moon. ${ }^{37} \mathrm{CHM}$ consists of three main features, including equitable sharing, equal participation, and peaceful usage. ${ }^{38}$ Resources discovered in the global commons belong to the whole of mankind, without individual States' ownership. ${ }^{39}$ The benefits deriving from CHM should thus be equally distributed to every State. Yet, which international institutions are in charge of "sharing the benefits in an equitable manner" is not always clear. ${ }^{40}$ Global adjudicative bodies like the ICJ could be possible instruments addressing benefit-allocation issues. ${ }^{41}$

In addition to equitable sharing, equal participation is another essential element to guarantee all States' interests on $\mathrm{CHM}^{42}$ Since every State has equal rights to

35 D. Hunter et al., International Environmental Law and Policy 452-3 (4th ed. 2010).

36 C. Joyner, Legal Implications of the Concept of the Common Heritage of Mankind, 35 INT'L \& ComP. L. Q. 191 (1986), available at https://www.cambridge.org/core/journals/international-and-comparative-law-quarterly/article/legalimplications-of-the-concept-of-the-common-heritage-of-mankind/27C87188CE97BA536F9FE5DD8E048C78 (last visited on Oct. 5, 2016).

37 E. Franckx, The 200-Mile Limit: Between Creeping Jurisdiction and Creeping Common Heritage? Some Law of the Sea Considerations from Professor Louis Sohn' Former LL.M. Student, 39 Geo. Wash. Int'L L. Rev. 470-1 (2007), available at https://www.questia.com/library/journal/1P3-1439064781/the-200-mile-limit-between-creepingjurisdiction. See also Yoshifumi Tanaka, Protection of Community Interests in International Law: The Case of the Law of the Sea, 15 Max Planck U.N.Y.B. 341 (2011), available at http://www.mpil.de/files/pdf3/mpunyb_07_Tanaka_15. pdf (all last visited on Oct. 5, 2016).

38 J. Van Dyke, Sharing Ocean Resources - In a Time of Scarcity and Selfishness, in The Law of the Sea: The Common Heritage and Emerging Challenges 4 (H. Scheiber ed., 2000).

39 Supra note 36.

40 S. Williams, The Law of Outer Space and Natural Resources, 36 INT'L \& CoMP. L. Q. 148 (1987), available at https:// www.cambridge.org/core/journals/international-and-comparative-law-quarterly/article/the-law-of-outer-space-andnatural-resources/78B61BF4A6222330F67577D0EE25E1E7 (last visited on Oct. 5, 2016).

$41 \quad I d$.

42 R. Wolfrum, The Principle of the Common Heritage of Mankind, 43 ZeITSChrift For Auslandisches OfFentLiches RECHT UND VolKerReCHT 332 (1983). 
CHM, not only the developed, but also developing States could have secured their right to participate. In other words, the institution prohibits any monopolistic activities of $\mathrm{CHM}$ and requires technology transfer. ${ }^{43}$

Finally, CHM can only be used for peaceful purposes. Take Article 3 of the Agreement governing the Activities of States on the Moon and Other Celestial Bodies (hereinafter Moon Treaty) ${ }^{44}$ as example. It stipulates that the moon "shall be used by all States Parties exclusively for peaceful purposes." 45 This article also prohibits "any hostile or threat of hostile act on the moon" and the weapons of mass destruction, inclusive of nuclear weapons, in orbit and military constructions around. ${ }^{46}$ It is believed that the exploitation and utilization of CHM should live up to the principle of sustainable development respecting social and economic development, and environmental protection to the future generations. ${ }^{47}$ Thus, peaceful utilization of $\mathrm{CHM}$ becomes a crucial global mandate although some treaties may not clearly articulate this emerging principle of international environmental law. ${ }^{48}$

\section{B. Types of CHM}

The concepts of the global commons and CHM are tightly but differently connected to each other. The global commons is the area to which State sovereignty does not apply, while CHM is the resources that exist in the global commons. Following this difference, types of CHM can be clearly identified and regulated effectively through the objectives of environmental sustainability.

Areas like the high seas and outer space have already been identified as part the global commons by the international community. Simultaneously, the sea-bed, the moon, and other celestial bodies appearing in outer space are recognized as CHM. However, there are some areas and resources that are still ambiguous in their status and require further discussion.

As for the sea-bed, the UNCLOS proclaims: "The Area and its resources are the common heritage of mankind." ${ }^{\prime 9}$ The 'Area' is defined as "the sea-bed and ocean

43 Id. at 323.

44 Agreement Governing the Activities of States on the Moon and Other Celestial Bodies, Dec. 5, 1979, 1363 U.N.T.S. 21 [hereinafter Moon Treaty].

45 Id. art. 3(1).

46 Id. art. 3(3).

47 Supra note 36, at 195.

48 K. Baslar, The Concept of the Common Heritage of Mankind in International Law 103-5 (1998).

49 United Nations Convention on the Law of the Sea of 1982, art. 136, 1833 U.N.T.S. 516 [hereinafter UNCLOS]. 
floor and the subsoil thereof, beyond the limits of national jurisdiction. ${ }^{, 50}$ Part XI of the UNCLOS stipulates the rules of the Area, including general provisions in Section 1 (Articles 133-135), principles governing the Area in Section 2 (Articles 136149), development of resources of the Area in Section 3 (Articles 150-155), and the Authority in Section 4 (Articles 156-191).

The implication and legal status of the sea-bed can mainly be derived from the UNCLOS. Article 137 regulates the legal status of the sea-bed and its resources. States shall not "claim or exercise sovereignty or sovereign rights over" any part of the sea-bed or its resources, nor shall any State or person "appropriate any part thereof." ${ }^{, 51}$ All rights in the sea-bed resources "are vested in mankind as a whole.,"52 Article 140 rules the benefits of the sea-bed. Activities in the sea-bed shall be "carried out for the benefit of mankind as a whole." ${ }^{, 53}$ The Authority shall provide mechanisms for the equitable sharing of benefits derived from activities in the seabed. ${ }^{54}$ Article 140 provides "the sea-bed shall be open to use for peaceful purposes by all States."

The concept of CHM has been also applied to the moon. Article 11.1 and 11.2 of the Moon Treaty stipulates that: "The moon and international natural resources are the common heritage of mankind...," which is "not subject to national appropriation by any claim of sovereignty, by means of use or occupation, or by any other means." Also, the exploration and utilization of the moon is articulated in Article 4 of the Moon Treaty:

\section{Article 4}

1. The exploration and use of the moon shall be the province of all mankind and shall be carried out for the benefit and in the interests of all countries, irrespective of their degree of economic or scientific development. Due regard shall be paid to the interests of present and future generations as well as to the need to promote higher standards of living and conditions of economic and social progress and development in accordance with the Charter of the United Nations.

2. States Parties shall be guided by the principle of co-operation and mutual assistance in all their activities concerning the exploration and use of the moon. International co-operation in pursuance of this Agreement should be as wide as possible and 
may take place on a multilateral basis, on a bilateral basis or through international intergovernmental organizations.

As to Antarctica, Australia, British, Chile, France, New Zealand, and Norway have claimed sovereignty on this continent. ${ }^{55}$ As none could continuously occupy Antarctica, however, these territorial claims are largely symbolic. ${ }^{56}$ The remote, frozen, isolated and uninhabitable character of Antarctica makes it retain the status of the global commons as well as $\mathrm{CHM} .^{57}$ In addition, resources in or on Antarctica are still largely unknown for mankind. The Antarctica Treaty ${ }^{58}$ adopted in 1959 has put territorial disputes into abeyance and pressed for international cooperation on scientific research. ${ }^{59}$

\section{Recognizing Atmospheric Absorptive Capacity as CHM}

The Earth's atmosphere, comprised of the mixture of gases and vital elements necessary for human survival, is not fully categorized as the global commons because of the dominance of State sovereignty. ${ }^{60}$ From a scientific perspective, however, the atmosphere is circulative, dynamic and fluctuating, which can never be effectively subject to the sovereignty of any State through territorial claims. ${ }^{61}$ Finally, recognizing the atmosphere as part of the global commons and regarding its resources as CHM is the key to overcoming the problem of the ineffective, inequitable and adverse use of its resources. ${ }^{62}$

The atmosphere is a layer of gases mixed with water vapor and aerosols surrounding the Earth and retained in place by its gravity. ${ }^{63}$ The major gases of the atmosphere are nitrogen $(78 \%)$, oxygen $(21 \%)$, argon $(0.9 \%)$ and carbon dioxide $(0.03 \%){ }^{64}$ The atmosphere can be divided into four primary layers, named 'atmospheric

55 S. Buck, The Global Commons: An Introduction 51-2 (2d ed. 1998).

56 P. Sands \& J. Peel, Principles of International Environmental Law 577-8 (3d ed. 2012).

57 J. Vogler, The Global Commons A Regime Analysis 75 (1995).

58 Antarctic Treaty, Dec. 1, 1959, 402 U.N.T.S. 71, available at http://hrlibrary.umn.edu/peace/docs/antarcticnuc.html (last visited on Oct. 5, 2016).

59 Supra note 55, at 59.

60 Id. at 111-2.

61 Supra note 57, at 124. See also D. Shelton, Equitable Utilization of the Atmosphere: A Rights-Based Approach to Climate Change?, in Human Rights and Climate Change 93 (S. Humphreys ed., 2010).

62 P. Cullet, The Kyoto Protocol and Vulnerability: Human Rights and Equity Dimensions, in Human Right and Climate Change 200 (S. Humphreys ed., 2010).

63 J. Shipman, Jerry Wilson \& Charles Higgins, An Introduction to Physical Science 547 (2015).

64 Id. 
stratification.' The first layer, the Troposphere, is 0 to 10 miles; the second layer, the Stratosphere, is 10 to 31 miles; the third layer, the Mesosphere, is 31 to 53 miles; and the fourth layer, the Thermosphere, is 53 to 375 miles. ${ }^{65}$ All these layers protect the Earth by absorbing radiation. ${ }^{66}$

Traditionally, the atmosphere contains two parts in terms of sovereignty: territorial airspace and non-territorial airspace. The former represents airspace which is above a State's land territory and territorial sea. It forms part of the State's jurisdiction. The extent of territorial airspace reaches at the Karman Line, at the altitude of 62 miles, which is the boundary between outer space and airspace. ${ }^{67}$ Outer space is the global commons outside territorial airspace.

When considering the whole atmosphere (both territorial airspace and nonterritorial airspace) as the global commons, however, it appears more reasonable and convincing in a legal manner. The nature of the atmosphere differs greatly from territory as we understand it. Territory is fixed on a specific region and more controllable by a State's sovereignty. In contrast, the atmosphere is dynamic, circulating and beyond a States' boundary that prevents it from being subject to real sovereign dominion. Meanwhile, the circulating property of the atmosphere forces all human beings in different States to endure negative environmental effects, such as transboundary air pollution and global warming, caused by activities in various States.

In order to prevent transboundary air pollution, international cooperation is a key strategy, but it does not work effectively most of the time. Basic principles of international law provide that a State has permanent sovereignty over natural resources. The Stockholm Declaration affirms that: "States have, in accordance with the Charter of the United Nations and the principles of international law, the sovereign right to exploit their own resources pursuant to their own environmental policies." ${ }^{\text {68 }}$ Neither developed nor developing countries are willing to give away 'resources' which are derived from sovereignty and allocated to them. ${ }^{69}$ Sovereignty still exists in all international cooperation plans and guarantees, to some extent, States' "right of pollution." ${ }^{, 70}$ It means that States have a 'right' to pollute the

65 H. Zell, Earth's Upper Atmosphere, NASA, available at http://www.nasa.gov/mission_pages/sunearth/science/mosupper-atmosphere.html (last visited on Oct. 5, 2016).

$66 \quad I d$.

67 L. Henkin, International Law: Politics and Values 178-80 (1995).

68 Stockholm Declaration, princ. 21, U.N. Doc. A/Conf.48/14/Rev. 1 (June 16, 1973), available at http://www.undocuments.net/aconf48-14r1.pdf (last visited on Oct. 5, 2016).

69 Henkin, supra note 67 , at 107-8.

70 Supra note 62, at 199. 
atmosphere over their territory by their economic activities.

The Kyoto Protocol sets up quantified emission limitations and reduction commitments for Annex I Parties of the UNFCCC. It diminishes the responsibility of atmospheric polluters by the 'grandfathering' mechanism. ${ }^{71}$ With this mechanism, industrialized Parties that have had previously higher polluting levels are imposed lesser reduction obligations than industrializing Parties. Thus, former States are still allowed to discharge large amounts of greenhouse gases, while latter States could be blocked from taking the traditional path of economic development because of tighter greenhouse gas emission obligations. ${ }^{72}$ Clearly, permanent sovereignty over natural resources still has a great impact on air pollution.

It is thus reasonable to define the atmosphere as global commons, such as the high seas and outer space. Here, States cannot abuse their 'territorial' sovereignty. ${ }^{73}$ Further, the "atmospheric absorptive capacity" can be recognized as CHM, because the absorptive ability neutralizes different gases to prevent adverse effects on human beings. ${ }^{74}$ In terms of greenhouse gases, this natural ability maintains a finite amount of greenhouse gases and guarantees a healthy global climate. ${ }^{75}$ However, since the industrial revolution, States and MNCs have continuously and increasingly overshot the "atmospheric absorptive capacity." The cumulative effects of overconsumption of resources have finally led to the global climate crisis. ${ }^{76}$ In order to deal with the crisis, governance principles of CHM should be adopted when allocating "atmospheric absorptive capacity."

\section{Atmospheric Governance: From ISA to IAA}

The UNCLOS is arguably the most robust treaty that lays out the managerial framework for the sea-bed as CHM. For the realization of the CHM concept, Article 137 of the UNCLOS provides: "All rights in the resources of the Area are vested in

71 Id.

72 Id.

73 See generally J. Harrison \& P. Matson, The Atmospheric Commons, in Protecting the Commons: A Framework for Resource Management in the Americas 219 (J. Burger et al. eds., 2001); S. Vanderheiden, Atmospheric Justice: A Political Theory of Climate Change 104 (2009).

74 D. Arnold, The Ethics of Global Climate Change 130 (2011).

75 Vanderheiden, supra note 73. See also N. Sachs, Climate Change Triage, 44 Envtl. L. 1000-2 (2014), available at http://papers.ssrn.com/sol3/papers.cfm?abstract_id=2346393 (last visited on Oct. 5, 2016).

76 Id. at 129. 
mankind as a whole, on whose behalf the Authority shall act. These resources are not subject to alienation. The minerals recovered from the Area, however, may only be alienated in accordance with this Part and the rules, regulations and procedures of the Authority." framework of ISA is an appropriate imitation that will ensure equitable sharing of the benefits deriving from the "atmospheric absorptive capacity" and its sustainable exploitation.

\section{A. Lessons from the International Sea-Bed Authority}

\section{Structure of ISA}

ISA is an intergovernmental organization created by the UNCLOS. ${ }^{78}$ The Authority is composed of three core organs: Assembly, Council, and Secretariat. ISA is in charge of economic benefits, sustainable exploitation and equitable distribution of the sea-bed on behalf of the whole of humanity, present or future.

The ISA Assembly acts as the 'supreme organ' to make its decisions and to elect the crucial policymakers. ${ }^{79}$ By and large, other organs of ISA need to take their agendas to the Assembly for approval. Meanwhile, the Assembly is required by the 1994 Agreement relating to the Implementation of Part XI of the United Nations Convention on the Law of the Sea (1994 Implementation Agreement) ${ }^{80}$ to collaborate with the Council when making policies and decisions. ${ }^{81}$

The Council, composed of 36 elected Parties, is considered as an 'executive organ. ${ }^{82}$ With four key tasks authorized by Article 162 of the 1994 Implementation Agreement, the Council appears to be the most powerful executive organ of the Authority in charge of supervising and coordinating the implementation of the UNCLOS. The Council approves sea-bed mining plans, makes recommendations,

77 UNCLOS art. 137(2).

78 F. Armas-Pfirter, How can Life in the deep sea be protected?, 24 InT'L J. MAR. \& COAST. L. 285 (2009), available at http://www.academia.edu/16461357/How_can_Life_in_the_Deep_Sea_Be_Protected (last visited on Oct. 5, 2016).

79 E. Franckx, The International Sea-bed Authority and the Common Heritage of Mankind: The Need for States to Establish the Outer Limits of their Continental Shelf, 25 InT'L. J. MAR. \& COAST. L. 549 (2010) available at http:///C:/ Users/USER/Downloads/248350.pdf (last visited on Oct. 5, 2016).

801994 Agreement Relating to the Implementation of Part XI of the United Nations Convention on the Law of the Sea of 1994, U.N. Doc. A/RES.48/263, 33 I.L.M. 1309 (1994) [hereinafter 1994 Implementation Agreement], available at https://documents-dds-ny.un.org/doc/UNDOC/GEN/N94/332/98/PDF/N9433298.pdf?OpenElement (last visited on Oct. 5, 2016).

81 R. Churchill \& A. Lowe, The Law of the Sea 245 (3d ed. 1988).

82 Supra note 79. 
and adopts and applies rules for exploration and exploitation in the sea-bed. ${ }^{83}$

The Secretariat functions as the 'administrative organ' of the Authority. It provides the Assembly and the Council with legal, technical and financial services. ${ }^{84}$

As subsidiary organs, ISA maintains the legal and technical commission and the finance committee. The Legal and Technical Commission ("LTC") is an influential supporting organ for the operation of the Authority. LTC makes recommendations to the Council for signing and licensing the sea-bed mining contracts, drafts rules and mining regulations, and supervises and assesses exploitation activities of seabed mining contractors. ${ }^{85}$ In addition, obligation fulfillment and environmental protection are two primary criteria for LTC to assess and to deliver approval recommendations to the Council. For obligation Statements in applicants' proposals, LTC needs to appraise whether applicants can comply with mining regulations and possess requisite financial and technical abilities. ${ }^{86}$ As to environmental protection, LTC focuses on assessing if exploration plans can benefit human beings and protect the marine environment under sustainable development principles. ${ }^{87}$ LTC also sets guidelines for contractors including environmental impact assessment, exploration expenditure report and training program design..$^{8}$

The Finance Committee is established on the basis of the 1994 Implementation Agreement. ${ }^{89}$ The membership of the Finance Committee follows the principle of equitable geographical distribution to ensure State Parties' equal participation. The Finance Committee is in charge of making recommendations for ISA on three aspects, including financial rule drafting, Authority budgeting, and economic benefit sharing. ${ }^{90}$

\section{Contracts between ISA and Other Parties}

Contracts between ISA and other parties are the key to equitably exploring and managing the sea-bed. Contractors can be enterprises, States parties, State enterprises

83 Supra note 81 , at $240-2$.

84 Supra note 79.

85 R. Wolfrum, Decision-Making in the Council: An Assessment and Comparison, in Law of the SEA at the Crossroads: The Continuing Search for a Universally Accepted Regime 68-70 (R. Wolfrum ed., 1990).

86 See International Seabed Authority, Decision of the Assembly of the International Sea-bed Authority Relating to the Regulations on Prospecting and Exploration for Polymetallic Sulphides in the Area, reg. 23, ISBA/16/A/12/Rev.1 (May 7, 2010), available at http://www.isa.org.jm/sites/default/files/files/documents/isba-16a-12rev1_0.pdf (last visited on Oct. 5, 2016).

87 Id.

88 Id.

891994 Implementation Agreement annex § 9.

90 Supra note 81, at 243. 
or natural or juridical persons that possess the nationality or are effectively controlled by them or their nationals. ${ }^{91}$ According to the Mining Code issued by ISA, applicants who plan to investigate, explore or exploit specific parts of the sea-bed are required to make application and sign contracts with the Authority. So far, State enterprises and juridical persons are the two main entities of contractors, which pursue win-win goals with the international community. ${ }^{92}$

Under the 15-year exploration contract, ${ }^{93}$ both ISA and the contractor bear specific rights and obligations. ISA needs to establish scientific databases and redistribute the benefits at lower cost and higher efficiency when the contractor makes annual scientific reports and relinquishes its exploring areas. Also, the Authority needs to conduct periodic reviews every five years to monitor the progress and environmental impact of the contractor's activities. ${ }^{94}$ The contractor, during the contracting time span, has the 'exclusive right' to carry out its research and exploration plan in the allocated areas. ${ }^{95}$ The contractor is allowed to retain 25 percent of its exploring areas for further exploitation after the expiration of the contract. ${ }^{96}$ Meanwhile, obligations imposed on the contractor include studying environmental baselines, updating scientific reports, protecting the environment, reporting emergent incidents, and relinquishing allocated areas. ${ }^{97}$ In order to meet the objective of sustainable utility of the sea-bed, there is also a need for the contract that can help a partner to make significant contributions to the scientific research and risk analysis.

\section{B. Establishing ISA and Enlisting MNCs}

"Atmospheric absorptive capacity" is a vital CHM, but it lacks an international managerial mechanism. ISA's experience provides a useful model for regulating this significant resource. After reviewing the structure and operation of ISA, it is recommended to establish a similar institution for the atmosphere, namely, the International Atmosphere Authority ("IAA"). Setting up IAA could be an effective way to avoid severe air pollution, to reach balance between economic growth and

91 Supra note 86 , reg. 9.

92 ISA, Deep Seabed Minerals Contractors, available at https://www.isa.org.jm/deep-seabed-minerals-contractors (last visited on Oct. 4, 2016).

93 Supra note 86 , reg. 28.

94 Id. regs. $30 \& 34$.

95 Id. reg. 2.

96 Id. reg. 27.

97 Id. regs. $27,30,34 \& 35$. 
air quality, and to enlist MNCs in the battle against global warming.

\section{Declaration of Principles Governing the Global Atmosphere}

In order to recognize "atmospheric absorptive capacity" as CHM and secure MNCs, in an effort to make them pay royalties and share benefits from using their capacity, the UN General Assembly should foremost make a declaration for establishing the atmospheric regulatory framework. ${ }^{98}$ Such a declaration can not only raise the awareness of the international community, but also ensure new principles for atmospheric management. By referring to the 1970 Declaration of Principles Governing the Sea-bed and the Ocean Floor, and the Subsoil Thereof, beyond the Limits of National Jurisdiction, ${ }^{99}$ key principles of the declaration shall deal with status identification, rules for the atmosphere and the Authority Governing atmospheric absorptive capacity. The declaration could read as follows:

1. The atmosphere is one of the global commons. The resource of the atmosphere, the atmosphere absorptive capacity, is the common heritage of mankind.

2. The atmosphere shall not be subject to appropriation by any means by States or persons, natural or juridical. States shall not claim or exercise sovereignty or sovereign rights over any part thereof.

3. No State or person, natural or juridical, shall claim, exercise or acquire rights with respect to the atmosphere or its resource incompatible with the international regime to be established and the principles of this Declaration.

4. All activities regarding the exploitation of the resource of the atmosphere and other related activities shall be governed by the international regime, the International Atmosphere Authority, to be established.

5. The exploration of the atmosphere and the exploitation of its resource shall be carried out for the benefit of mankind as a whole, and take into particular consideration the interests and need of the developing countries.

6. On the basis of the principles of this Declaration, an international regime applying to the atmosphere and its resource and including appropriate international machinery to give effect to its provisions shall be established by an international treaty of a universal character, generally agreed upon. The regime shall, inter alia, provide for the orderly and safe development and rational management of the atmosphere

C. Antrim, Mineral Resources of Stateless Space: Lessons from the Deep Seabed, 59 J. InT'L AfF. 56 (2005), available at https://www.questia.com/library/journal/1G1-140163621/mineral-resources-of-stateless-space-lessons-from (last visited on Oct. 5, 2016).

99 UN Declaration of Principles Governing the Sea-bed and the Ocean Floor, and the Subsoil Thereof, beyond the Limits of National Jurisdiction, U.N. Doc. A/RES/25/2749 (Dec. 17, 1970), available at http://www.un-documents.net/ a25r2749.htm (last visited on Oct. 5, 2016). 
and its resource and for expanding opportunities in the use thereof and ensure the equitable sharing by States in the benefits derived therefrom, taking into particular consideration the interests and needs of the developing countries, the atmosphere and its resource.

\section{Structure of IAA}

Without an international level authority in charge of atmospheric management, a variety of environmental problems, such as toxic gas emissions and global warming would become worse. In order to resolve these problems, IAA could be the key in international regime to regulating exploitation of atmospheric absorptive capacity. The basic operational system of IAA could be modelled after the ISA structure.

The IAA structure could be composed of core organs and subsidiary organs taking different responsibilities. There are three core organs - Assembly, Council, and Secretariat. The Assembly will be the supreme organ, with the power to make final decisions and structure policies for IAA. The Council will be the 'executive organ' composed of State Parties elected by the Assembly. The Council controls substantive powers of IAA by approving atmospheric exploration, exploitation plans and the financial decision-making. The Secretariat will be the 'administrative organ' in charge of internal administrative work and the management of public relationships with NGOs, external international organizations and State Parties.

LTC as a subsidiary organ would exercise an influential status in the IAA decision-making processes. LTC's recommendations would be the bases for the Council's final decisions. LTC would draft rules relating to "atmospheric absorptive capacity." It would undertake the monitoring and assessment of exploration and exploitation activities. The Finance Committee would be the other subsidiary organ in charge of financial issues.

\section{Contracts between IAA and MNCs}

MNCs are major producers of global greenhouse gases. These big firms are consuming most of the "atmospheric absorptive capacity." However, MNCs are out of international conventions because they are not subjected to international law. MNCs would thus take advantage of the ambiguous status and poor legal regimes (usually in developing countries) to create tremendous wealth by emitting unrestrained greenhouse gases when producing their goods.

Signing contracts regarding "atmospheric absorptive capacity" can be an effective strategy and instrument for IAA to lay out rights and duties for MNCs and to ensure three requirements of CHM: equitable sharing, equal participation, and 
peaceful usage. Equitable sharing forces MNCs to share benefits deriving from the consumption of "atmospheric absorptive capacity." Equal participation guarantees each MNC the access to utilize "atmospheric absorptive capacity." Finally, peaceful usage requires the safe and sustainable exploration and exploitation of the atmosphere.

The international legal regime is able to balance interests between MNCs and the stakeholders of the atmosphere, such as States, local governments, communities and individuals, through the design of the contract. MNCs gain significant profits from business activities which consume large portions of "atmospheric absorptive capacity." With the royalty paid by MNCs, IAA can redistribute benefits to the stakeholders and especially climate victims. ${ }^{100}$ While paying for the right to consume "atmospheric absorptive capacity," MNCs should take necessary actions to monitor and protect the atmosphere from irreversible impacts caused by their activities.

Under the contracts, MNCs would be required to provide annual scientific reports concerning their consumption of "atmospheric absorptive capacity" to IAA. Following the reports, the Authority can establish a worldwide database that can contribute to its decision-making process. The contract should articulate the scientific reports to be measurable, reportable, and verifiable ("MRV"). ${ }^{101}$ The process of measurement can help MNCs to establish baselines and exactly calculate their consumption of "atmospheric absorptive capacity." 102 The MNCs' activities and data report can allow IAA to collect all the facts, evidence and information needed for scientific atmospheric governance, i.e., equitable sharing, equal participation, and peaceful usage. ${ }^{103}$ If verified, MNCs' reports can improve MNCs' ability to facilitate the reduction of their consumption of "atmospheric absorptive capacity."104

Consequently, it is essential to have technology transfer clauses in the contract. MNCs are required to transfer their technologies to IAA, which will be more effective and economical to combat global warming. MNCs are the main patent holders of environmentally sound technologies, including the key skills and knowledge to reduce greenhouse gas emissions. However, patent licensing is

100 Pooja Bhatia \& Archana Chugh, Role of Marine Bioprospecting Contracts in Developing Access and Benefit Sharing Mechanism for Marine Traditional Knowledge Holders in the Pharmaceutical Industry, 3 Global Ecology \& CONSERVATION 179 \& 185 (2015), available at http://www.sciencedirect.com/science/article/pii/S2351989414000857 (last visited on Oct. 5, 2016).

101 A. Genest, The Fight against Global Warming: Progress Made and Priorities for a Successor to the Kyoto Protocol, 46 La Revue Juridique Thémis de L'Université de Montréal 533 (2013), available at https://ssl.editionsthemis.com/ uploaded/revue/article/14398_Genest-1.pdf (last visited on Oct. 5, 2016).

102 C. Breidenich \& D. Bodansky, Measurement, Reporting and Verification in a Post-2012 Climate Agreement 11-7 (2009).

103 Id.

104 Id. 
frequently abused or impeded when MNCs fear the creation of potential competitors among developing countries. ${ }^{105}$ Acquiring high-tech patent licensing through the contract process, IAA can take advantage of managing the atmosphere and support stakeholders with lower costs.

\section{A Model Contract for Exploitation of "Atmospheric Absorptive Capacity"}

The ISA Assembly adopted the decision relating to "the regulations on prospecting and exploration for polymetallic sulphides in the Area" on May 7, 2010. The regulations incorporate a "contract for exploration" document in Annex 3 and the "standard clauses for exploration contract" document in Annex 4. ${ }^{106}$ Both documents can be tailored and revised to become a model contract for the exploitation of "atmospheric absorptive capacity" as follows.

THIS CONTRACT made the day of ___ By and Between the International Atmosphere Authority represented by its Secretary-General, with full powers, (hereinafter referred to as "the Authority") and represented by (hereinafter referred to as "the Contractor"), as duly authorized; WITNESSETH; WHEREAS as follows:

\section{Incorporation of Clauses}

A. The standard clauses set out in Annex 1 to the Regulations on the Exploitation of atmospheric absorptive capacity of the Area shall be incorporated herein and shall have effect as if herein set out at length.

\section{Resource Exploitation}

B. For the purposes of this contract, "resource exploitation" means that part of atmospheric absorptive Capacity of the Area allocated to the Contractor for exploitation, defined by the coordinates listed in Schedule 1 hereto, as reduced from time to time in accordance with the standard clauses and the Regulations.

\section{Grant of Rights}

C. In consideration of:

(1) Their mutual interest in the conduct of resource exploitation in the Area pursuant to the Convention and the Agreement.

105 Id. C. Hutchison, Does TRIPS Facilitate or Impede Climate Change Technology Transfer into Developing Countries?, 3 U. ОттAwa L. \& Tесн. J. 529 (2006), available at http://www.uoltj.ca/articles/vol3.2/2006.3.2.uoltj. Hutchison.517-537.pdf (last visited on Oct. 5, 2016).

106 Id. Supra note 83, at 34-49. 
(2) The responsibility of the Authority to organize and control resource exploitation in the Area in accordance with the legal regime established in Article of the Convention and the Agreement; and

(3) The interest and financial commitment of the Contractor in conducting resource exploitation in the Area and the mutual covenants made herein, the Authority hereby grants to the Contractor the right to exploit atmospheric absorptive capacity of the Area in accordance with the terms and conditions of this contract.

\section{Entry into Force and Contract Term}

D. This contract shall enter into force on signature by both parties and, subject to the standard clauses, shall remain in force for a period of five years thereafter.

\section{Schedules}

E. This contract expresses the entire agreement between the parties, and no oral understanding or prior writing shall modify the terms hereof.

\section{Entire Agreement}

F. This contract expresses the entire agreement between the parties, and no oral understanding or prior writing shall modify the terms hereof.

IN WITNESS WHEREOF the undersigned, being duly authorized thereto by the respective parties, have signed this contract at _, this _ day of _

\section{Schedule 1}

[Coordinates and illustrative chart of the resource exploitation]

\section{Conclusion}

Most people are not aware that the world is changing and most of those, who acknowledge such change, often choose to ignore or are afraid of recognizing the situation. However, the world keeps changing just as surely as the Earth rotates. After all, the world is connected and the State-centric system is diffused in the twenty-first century. Anne-Marie Slaughter writes: ${ }^{107}$

107 A.-M. Slaughter, America's Edge: Power in the Networked Century, 88 ForeIGN AfF. 94-5 (2009), available at https:// www.foreignaffairs.com/articles/united-states/2009-01-01/americas-edge (last visited on Oct. 5, 2016). See also J. Wiener, The Diffusion of Regulatory Oversight, in The Globalization of Cost-Benefit Analysis in Environmental Policy 130 (M. Livermore \& R. Revesz eds., 2013). 
We live in a networked world. War is networked. ... Diplomacy is networked. ... Business is networked. ... Media are networked. ... Society is networked. ... Even religion is networked. ... In this world, the measure of power is connectedness. ... The twentieth-century world was, at least in terms of geopolitics, a billiard-ball world, described by the political scientist Arnold Wolfers as a system of self-contained States colliding with one another. The results of these collisions were determined by military and economic power. ... The emerging networked world of the twenty-first century, however, exists above the State, below the State, and through the State. In this world, the State with the most connections will be the central player, able to set the global agenda and unlock innovation and sustainable growth...

Similarly, the State-centric approach to combat climate change has proven deficient. There are few existing incentives for Annex I Parties and non-Annex I Parties to fight against climate change. The status quo does not incorporate MNCs into the international climate change legal regime, either. So far, the real and major greenhouse gas emitters, MNCs, are still outside the global regulatory framework and bear little responsibility in the global warming networks. MNCs, as private actors without Statehood, are free from international legal obligations to reduce greenhouse gas emissions and allowed to discharge those gases 'legally' in the States who take light measures to tackle global warming. Since MNCs make tremendous profits at the expense of all mankind, it is important to recognize "atmospheric absorptive capacity" as CHM and place MNCs on the networked track for global environmental and equitable sustainability.

\section{Annex}

\section{Standard Clauses}

\section{Section 1 - Definition}

1.1 In the following clauses:

(a) "Area" means the atmosphere of the Earth.

(b) "Resource Exploitation" means that part of Atmospheric Absorptive Capacity of the Area allocated to the Contractor for exploitation.

(c) "Regulations" mean the Regulations on the Exploitation of Atmospheric Absorptive Capacity of the Area, adopted by the Authority.

1.2 Terms and phrases defined in the Regulations shall have the same meaning in these standard clauses.

1.3 This contract includes the schedules to this contract, which shall be an integral part thereof. 


\section{Section 2 - Security of tenure}

2.1 The Contractor shall have security of tenure and this contract shall not be suspended, terminated or revised except in accordance with section 8 hereof.

2.2 The Contractor shall have the right to exploit atmospheric absorptive capacity of the Area in accordance with the terms and conditions of this contract.

2.3 The Contractor, by notice to the Authority, shall have the right at any time to renounce without penalty the whole or part of its rights in the Area, provided that the Contractor shall remain liable for all obligations accrued prior to the date of such renunciation in respect of the area renounced.

2.4 Nothing in this contract shall be deemed to confer any right on the Contractor other than those rights expressly granted herein. The Authority reserves the right to enter into contracts with respect to resources with third parties in the Area covered by this contract.

\section{Section 3 - Contract term}

3.1 This contract shall enter into force on signature by both parties and shall remain in force for a period of five years.

3.2 Upon application by the Contractor, not later than six months before the expiration of this contract, this contract may be extended for periods of not more than five years each on such terms and conditions as the Authority and the Contractor may then agree in accordance with the Regulations. Such extensions shall be approved if the Contractor has made efforts in good faith to comply with the requirements of this contract.

\section{Section 4 - Annual report}

The Contractor shall, within 90 days of the end of each calendar year, submit a report to the Secretary-General in such format according to the measurable, reportable, and verifiable principles as may be recommended from time to time by the Legal and Technical Commission covering its exploitation of atmospheric absorptive capacity of the Area and sufficient detail.

\section{Section 5 - Royalty payment}

The Contractor shall, within 90 days of the end of each calendar year, pay its royalty to the Secretary-General on the basis of the payment formula as may be recommended from time to time by the Legal and Technical Commission.

\section{Section 6 - Data and information to be submitted on expiration of the contract}

The Contractor shall transfer to the Authority all data and information that are both necessary for and relevant to the effective exercise of the powers and functions of the Authority in respect of the resource exploitation in the Area in accordance with the provisions of this section.

\section{Section 7 - Inspection}

7.1 The Contractor shall permit the Authority to send its inspectors to monitor the Contractor's 
compliance with the terms and conditions of this contract and the Regulations.

7.2 The Secretary-General shall give reasonable notice to the Contractor of the projected time and duration of inspections, the name of the inspectors and any activities the inspectors are to perform that are likely to require the availability of special equipment or special assistance from personnel of the Contractor.

\section{Section 8 - Revision}

8.1 When circumstances have arisen or are likely to arise which, in the opinion of the Authority or the Contractor, would render this contract inequitable or make it impracticable or impossible to achieve the objectives set out in this contract the Agreement, the parties shall enter into negotiations to revise it accordingly.

8.2 This contract may also be revised by agreement between the Contractor and the Authority to facilitate the application of any rules, regulations and procedures adopted by the Authority subsequent to the entry into force of this contract.

8.3 This contract may be revised, amended or otherwise modified only with the consent of the Contractor and the Authority by an appropriate instrument signed by the authorized representatives of the parties.

\section{Section 9 - Disputes}

Any final decision rendered by a court or tribunal having jurisdiction under the Convention relating to the rights and obligations of the Authority and of the Contractor shall be enforceable in the territory of any State Party to the Convention affected thereby.

\section{Section 10 - Interpretation}

The division of this contract into sections and subsections and the insertion of headings are for convenience of reference only and shall not affect the construction or interpretation hereof.

\section{Section 11 - Additional documents}

Each party hereto agrees to execute and deliver all such further instruments, and to do and perform all such further acts and things as may be necessary or expedient to give effect to the provisions of this contract. 